\title{
Travelers' Responsible Environmental Behavior towards Sustainable Coastal Tourism: An Empirical Investigation on Social Media User-Generated Content
}

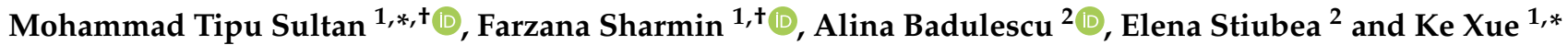 \\ 1 School of Media and Communication, Shanghai Jiao Tong University (SJTU), Shanghai 200240, China; \\ sharminf@sjtu.edu.cn \\ 2 Department of Economics and Business, University of Oradea, 410087 Oradea, Romania; \\ abadulescu@uoradea.ro (A.B.); elena_stiubea@yahoo.com (E.S.) \\ * Correspondence: tipusultan_ctg@sjtu.edu.cn (M.T.S.); kxue@sjtu.edu.cn (K.X.) \\ + Mohammad Tipu Sultan and Farzana Sharmin equally contributed as the first author to this work.
}

Citation: Sultan, M.T.; Sharmin, F.; Badulescu, A.; Stiubea, E.; Xue, K. Travelers' Responsible Environmental Behavior towards Sustainable Coastal Tourism: An Empirical Investigation on Social Media User-Generated Content. Sustainability 2021, 13, 56. https://dx.doi.org/10.3390/su1301 0056

Received: 11 November 2020 Accepted: 18 December 2020

Published: 23 December 2020

Publisher's Note: MDPI stays neutral with regard to jurisdictional claims in published maps and institutional affiliations.

Copyright: () 2020 by the authors. Licensee MDPI, Basel, Switzerland. This article is an open access article distributed under the terms and conditions of the Creative Commons Attribution (CC BY) license (https: / / creativecommons.org/ licenses/by/4.0/).

\begin{abstract}
There has been increasing interest in coastal tourism, sparking a debate on the responsible environmental behavior of travelers visiting sustainable destinations. To mitigate this issue, destination marketing organizations (DMOs) and environmental activists are trying to develop strategic approaches (i.e., by using digital technologies) to enhance the sustainable behavior of travelers. Environmental responsiveness and its impact on sustainable destinations is gaining attention by companies, scholars, and institutions. However, the relevant literature has not addressed social media user-generated content regarding sustainable destinations. Sharing stakeholder knowledge, activities, and experience on social media could accomplish this goal. Hence, this paper aims to explore travelers' responsible environmental behavior towards coastal tourism within the social media user-generated content paradigm. To measure the effect of user-generated content (UGC), i.e., cognitive triggers and affective triggers, on the responsible environmental behavior of travelers, a survey questionnaire was used to collect data $(n=506)$ from the world's longest sandy sea beach, Cox's Bazar, located in the Southern part of Bangladesh. The data were examined by structural equation modeling (SEM). The results revealed that cognitive and affective triggers of user-generated content influence travelers' environmental concerns and attitudes, making a significant contribution to shaping responsible environmental behavior. Additionally, the findings show that environmental concerns and attitudes play a significant role in producing commitment towards a sustainable coastal tourism practice. This study contributes to the effectiveness of user-generated content for persuasive interactions with destination marketing organizations to develop sustainable tourism practices.
\end{abstract}

Keywords: environmental attitude; environmental concern; sustainable coastal tourism; social media; responsible environmental behavior; user-generated content

\section{Introduction}

Coastal tourism is an emerging sector within the world tourism industry. Millions of travelers visit coastal beaches for recreational activities, such as surfing, swimming, and camping [1]. These emerging tourism trends are important in coastal tourism due to their entertainment elements [2,3], such as "sea, sun, and sand" with "a relaxed friendly" atmosphere. Besides recreational activities, coastal tourism provides economic contributions to destinations $[4,5]$. However, the interest in coastal tourism raises new issues regarding the ecological status and sustainability of the host communities [6,7]. All facilities and services, primarily designed to be used by residents, are now suffering from a growing number of people looking for tourism activities that are interlinked with local customs [8]. Such advancements have led to increased pressure on host communities, sparking a debate on the compatibility of the environment with human activities. In recent decades, these regions have been plagued by harmful algal blooms, coastal corrosion, land reclamation, 
etc. $[9,10]$. As a result, coastal destinations play a crucial role in sustainable tourism marketing. Sustainable coastal tourism remains challenging due to the prevalence of irresponsible behavior by tourists, which acts as a barrier to the sustainable environmental conservation of the destination.

Research suggests that environmental sustainability and protection are crucial considerations for the sustainable growth of coastal tourism. Conserved marine environments and sea beaches provide opportunities for open spaces and recreational activities [2]. Therefore, beaches are the most important assets of coastal tourism, which need to be adequately preserved and, subsequently, can contribute to the sustainable economic development of the industry [11]. Hence, it has become exponentially important for beach management authorities to consider the major factors that influence the responsible attitudes of tourists regarding coastal destinations. Moreover, traveler behavior is identified as a critical issue for the tourism sector, because multiple negative effects are attributed to the poor behavior of travelers to the destination [12]. A wide body of literature has been developed to understand the responsible environmental behavior of tourists $[13,14]$ and their decision-making behavior (i.e., visit intention, destination choice) $[14,15]$. Travelers' responsible environmental behavior (REB) describes individual or group actions that promote (or result in) the sustainable use of natural resources. Globally, environmental consciousness of travelers has increased in recent decades. These changes have been driven by a variety of factors, including greater awareness, public pressure, environmental legislation, increased media coverage, and changing public opinion [16]. However, the coastal tourism industry is still "far from sustainable" [17]. Environmental issues must be taken into account because of destination competitiveness and, indeed, many tourist activities directly depend on the quality of natural resources of destinations.

Environmental awareness and practices of tourists have become vital concerns for destination marketing organizations (DMOs) [18]. They promote sustainable environmental consciousness campaigns and attempt to encourage tourists to actively adopt environmentally friendly attitudes $[19,20]$. Moreover, many coastal destinations have not developed any effective strategies and awareness-building activities to influence tourists ${ }^{\prime}$ psychological well-being. In this situation, social media user-generated content may play a significant role in reshaping tourists' environmental consciousness towards coastal destinations $[14,21,22]$. In recent years, social media has become a documented and significant source of tourist information [23-25]. Members of these virtual platforms create environmental awareness through user-generated content (UGC) and influence their peers' attitudes $[14,26]$. For instance, Facebook is an innovative information source for the essential ties between the green ideals of travelers and behavioral changes [27]. Other research investigated and contrasted the usage of social media to encourage positive travel actions and environmental movements in three cultural contexts [28]. This research found that online posts, messages, or interactions were more convincing than the information provided by tour operators. Thus, environmentally related UGC also requires persuasive engagement between peers and affects travelers' responsible tourism practices. However, there is a lack of documented data on social media's influence and traveler responsibility regarding coastal areas. To address this research gap, the current study aims at addressing the following research questions:

RQ 1. Could social media UGC influence environmental concerns and attitudes towards sustainable coastal tourism?

RQ 2. Could social media UGC encourage responsible environmental behavior in travelers?

To address these research questions, this paper's aims are: (i) suggesting a model of sustainable coastal tourism and responsible environmental behaviors of travelers, and (ii) empirically analyze the proposed structure within the context of social media UGC (i.e., cognitive triggers and affective triggers). The paper is structured as follows. First, it reviews the extant literature by outlining the key aspects of sustainable coastal tourism, discussing the critical elements of sustainable and responsible environmental behavior, the key issues in the field of social media UGC (i.e., cognitive and affective triggers), and their 
impact on travelers' behavior. Then, it presents discussion resulting in the framework of suggested REB within the social media paradigm. This is followed by the study aiming at empirically testing and validating the suggested framework within the sustainable tourism context. The study's findings are then presented and discussed, followed by theoretical and managerial context. Finally, the main conclusions are discussed, together with the study limitations and suggestions for future research.

\section{Literature Review and Hypothesis Formulation}

\subsection{Sustainable Coastal Tourism}

Sustainability is defined as achieving sustainable development (the most widespread and well-known concept associated with sustainability) without compromising future generations' ability to meet their own needs [29]. "Sustainable development" was introduced by the UN in 1987 [29]. Since the late 1980s, sustainability has received extensive attention as a serious problem in the tourism sector. It describes ecological problems and the limited capacity of destination management. In the late 1990s, the concept was extended to address three issues that go beyond environmental protection towards sustainability. Firstly, the environmental dimension, which relates to fundamental ecological processes, natural heritage conservation, and biodiversity; secondly, the social-cultural elements of violence, urban society, and crowdedness; and finally, the economic dimension that affects foreign investors and the local employment marketplace [29].

Several factors explain the concerns of sustainability in the tourism sector, such as economic benefits, which create employment, increase revenue, affect different sectors, and rely on the cultural heritage and landscape of the destination. Thus, this sector has become the fastest-growing industry in the world [30]. Coastal areas represent a significant part of this growth, attracting hundreds of millions of tourists each year. These areas are one of the most profitable tourism sectors [31] and are strongly acknowledged as seasonal travel attractions [32]. Conversely, coastal regions have also been facing negative environmental and socio-cultural effects, and a gradual loss of the destination's attractiveness and competitiveness [33]. To ensure the sustainability of coastal tourism, a balance between economic benefits and socio-cultural/environmental conservation is required.

Coastal tourism is interconnected with leisure and recreation activities that take place throughout coastal regions. The development of coastal tourism is connected to accommodation, transportation, restaurants, and the food processing industry. Infrastructure construction supports various activities, such as leisure boating, beach cruises, sailing, recreational fishing, scuba diving, and swimming [33,34]. This sector also comprises shore-based events, such as beach walking, cruise ship services, and yacht activities. Ultimately, beaches are the most vital resources of coastal tourism. However, its attractiveness is slowly crumbling because of environmental pollution and irresponsible behavior by tourists. Many studies have shown that different beach destinations face various types of pollution from travelers and residents due to inadequate awareness and the implementation of protective policies [35-38]. Prior research found that coastal ecosystems are increasingly vulnerable due to increased human activity. As with other dimensions of tourism, concerns about the effects on the physical environment and its associated aspects of sustainable development have gained momentum in coastal tourism research. To maintain continuous tourism activities, sustainable practices and their derivatives need to be promoted. Social media can play an important role in building REB to achieve sustainable coastal tourism.

\subsection{Social Media User-Generated Content}

The creation/interaction of social media UGC is gaining popularity and has become an essential tool for bridging the online community. At the individual level, UGC helps travelers express their opinions and permits interaction with others to gather or disseminate information [39]. This opportunity motivates the community or peers to express their opinions, experiences, and perspectives $[39,40]$. Social media content includes all information shared on a digital platform, including pictures, tags (text descriptions and 
geolocalization), etc. This content reflects individual user values regarding tangible and intangible aspects of the environment [41]. More importantly, various online virtual communities have been valuable sources of information for sustainable behavioral change [23]. A study identified that social media UGC positively and significantly affects the image of a destination, as well as attitudes, and the intention to visit said destination [24,42]. Another paper explored and compared the way social media is used in promoting responsible travel behavior and how sustainable actions influence community awareness [14]. Environmentrelated UGC also aims to encourage persuasive communication that affects tourist attitudes and actions towards responsible environmental behavior [34].

Prior studies have recognized the crucial role of environmental dialogue in the online travel community, in regards to laying the groundwork for collaborative development $[14,43,44]$. By sharing travel experiences, community members have received environmental knowledge that influences their beliefs, sensitivities, and perceptions towards "green" or "eco" activities $[25,44]$. To this point of view, the current study defines this environmental knowledge as a cognitive trigger of UGC. On the other side, an empirical study documented that Facebook can act as an innovative platform that could bridge the required gaps between green values and behavioral change [27]. Studies also explored and compared the impact of social media campaigns on responsible travel behavior and sustainable actions in different cultural contexts. From a technical perspective, active and ambitious tourists, with their aspirations and requirements for customized and sustainable experiences, might be co-creators of experience and co-managers of tourism resources. Previous studies examined how an effective social media conversation can promote an agenda for sustainable consumption awareness and practices into online lifestyles [42]. The findings of one such study revealed that online information was more convincing than that provided by tour operators [45]. Based on this, the present study defines environmental awareness or consciousness as an affective trigger of UGC. However, the effect of cognitive and affective factors through UGC perceptions of individual responsible environmental behavior towards coastal tourism is still under-researched, especially concerning environmental issues.

\subsubsection{Cognitive Triggers}

Social media UGC psychologically empowers cognitive development in travelers, and cognitive triggers influence affective responses and attitudes. This empowerment is a process through which people gain control over their lives, it improves strength and skills, and enhances proactive behaviors to achieve their social affairs. In cognitive psychology, these factors are referred to as the "cognition—affection—attitude-intention" framework for the behavioral intention procedure [46]. In the context of sustainable tourism, this factor refers to the awareness of environmental complications, accountability, biosphere value, and ecological concern [47-49], which is recognized as a clear understanding or knowledge of environmental protection, natural environments, and ecosystems. These cognitive assessments and perceptions become the beliefs of environmental knowledge [50]. Individuals can determine their capabilities through an understanding of the level of environmental knowledge. Previous studies have shown that the environmental knowledge of tourists is mostly built from the perspectives of environmental education, environmental problems, and environmental action strategies [51]. Most notably, travelers gain a better understanding of environmental issues by visiting the destination. Consequently, their shared practical information as UGC could enhance the environmental concerns of future travelers and influence their attitudes to perform sustainable responsible behavior. Thus, the following hypotheses are formulated:

Hypothesis 1a (H1a). The cognitive triggers of UGC have a positive influence on environmental concerns.

Hypothesis $\mathbf{1 b} \mathbf{( H 1 b ) . ~ T h e ~ c o g n i t i v e ~ t r i g g e r s ~ o f ~ U G C ~ h a v e ~ a ~ p o s i t i v e ~ i n f l u e n c e ~ o n ~ e n v i r o n m e n t a l ~}$ attitudes. 


\subsubsection{Affective Triggers}

Affective triggers reflect individual perceptions of the world from an environmentally friendly perspective [47]. Two major components contribute to affective triggers; firstly, individuals' favorable attitudes towards the environment, and secondly, positive actions towards the environment through responsible behavioral intention [44,52]. According to Hungerford and Volk [53], the empathetic feeling for the environment has been identified as one of the contributing factors to responsible environmental citizenship. This framework integrates environmental sensitivity with responsible environmental behavior towards sustainable coastal destinations.

In the context of responsible environmental behavior, affective triggers reflect individual perceptions of the world from an empathetic perspective [47]. Previous studies verified that individuals with more environmental knowledge have enhanced environmental concerns [54]. Another study characterizes affection as a psychological feeling that is sensitive to the environment and generates internal environmental concerns [55]. It has been recommended that the higher level of environmental knowledge of travelers enhances their environmental sensitivity and, as a consequence, these environmental sensitivities influence the action of the environmental attitude. In the context of UGC in social media communities, it is assumed that the sensitivity of an individual's perception could be enhanced. Thus, the following hypotheses have been proposed:

Hypothesis 2a (H2a). The affective triggers of UGC have a positive influence on environmental concerns.

Hypothesis $\mathbf{2} \mathbf{b} \mathbf{( H 2 b )}$. The affective triggers of UGC have a positive influence on environmental attitudes.

\subsection{Environmental Concern and Responsible Environmental Behavior}

Environmental concern is the principal determinant of the sustainable consumption of the environment $[51,56,57]$. This factor is referred to as "emotional attachment towards environmental concerns", which is identified as the association of an individual to the environment [58]. The environmental concerns of tourists are connected with an interest in the biophysical environment and its problems. It has been documented that individual expressions of environmental concerns are grounded on product characteristics, information, and benefits [51,53]. It also reflects the responsiveness and commitment of individuals or groups to protect the environment through environmental responsibility. Sustainability and environmental concern is a rising global phenomenon that is closely linked to the responsible environmental behavior (REB) $[28,59]$ Previous studies have reported a lack of concern as the major cause of irresponsible behavior towards the destination or environment $[22,60]$. Therefore, environmental concern and awareness building have become a core topic for REB. However, the understanding of social media's impact on sustainable coastal tourism is still in its infancy, especially in terms of responsible behavioral intention. Thus, to assess travelers' REB, the current study considered environmental concern as a mediating factor [60], in that REB is reflected in responsible actions, having the least negative impact while traveling to a coastal destination [58]. In the context of tourism, a higher environmental concern induces an optimistic attitude towards sustainable practice commitment $[19,59]$. However, the association between environmental concern and travelers responsible environmental behavior through UGC is still under research. According to this discussion, this study assumed that, through UGC interaction, environmental concerns would be strengthened by direct experience or opinion. Thus, it is expected that:

Hypothesis 3a (H3a). Environmental concern has a positive influence on environmental attitudes.

Hypothesis $\mathbf{3 b} \mathbf{( H 3 b )}$. Environmental concern has a positive influence on responsible environmental behavior towards coastal tourism. 


\subsection{Environmental Attitude and Responsible Environmental Behavior}

Attitude is identified as the degree of an individual's positive or negative assessment towards a specific behavior [52]. In the tourism context, environmental attitudes are often referred to as an individual's favorable or unfavorable approach to specific aspects of the environment [61]. Many studies focused on the attitude-behavior association and highlight that attitude is a vital modifier of an individual's environmental behavior [62,63]. Prior research suggests that attitude toward environmental behavior is the main strength of a positive evaluation and, subsequently, influences the engagement of environmentally responsible behavior [64]. The research suggested a linear combination of awareness, attitude, and environmental behavioral intention [65], which demonstrates the influencing factor of REB [66]. According to Hines et al. [54], responsible environmental behavior is associated with individual awareness, attitudes, and sense of responsibility. Hence, social media-based environmental motivation can be more effective and influence an individual's sense towards environmental attitudes [14], which found as a strong triggering role in developing environmental norms and increasing the commitment of travelers to REB. As a result, environmental attitude has become a relevant predictor of responsible environmental behavior. Based on the above discussion, the following hypothesis has proposed:

Hypothesis 4 (H4). Environmental attitude has a positive influence on responsible environmental behavior towards coastal tourism.

The proposed conceptual model is provided in Figure 1.

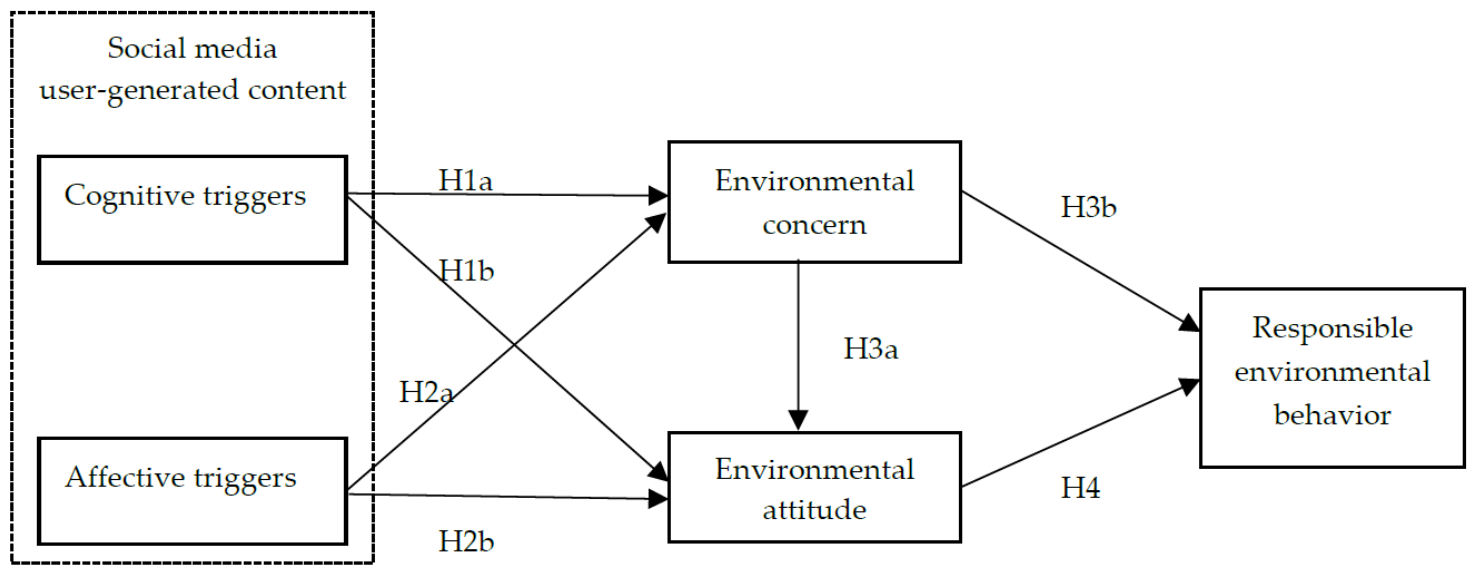

Figure 1. The conceptual model.

\section{Research Methods}

\subsection{Overview of the Study Area}

Cox's Bazar, is famous for the world's longest sandy sea-beach, with an unbroken length of $155 \mathrm{~km}(96 \mathrm{mi})$, located in the south-east district of Bangladesh (see Figure 2). This place is famous for coastal tourism, natural beauty, and tribal culture. This site is also considered as a tourist hub and is recognized as the tourism capital of the country. This beach is situated in the Bay of Bengal, which is a famous destination for domestic tourists only. The lack of promotional activities hinder international recognition and economic benefits. Different sectors of Cox's Bazar Beach have different names, usually referring to the region in which they are located. Among the most popular sections are Kolatoli Beach, Humchari Beach, Laboni Beach, and Inani Beach. The beachside coastal area of Cox's Bazar is a popular tourist attraction for a huge number of beach travelers throughout the year. While it has an enormous opportunity to develop as one of the most desirable coastal destinations, it is also plagued by environmental pollution issues, such as beach erosion and water pollution. Thus, the environmental sustainability of this coastal area needs to be investigated. 

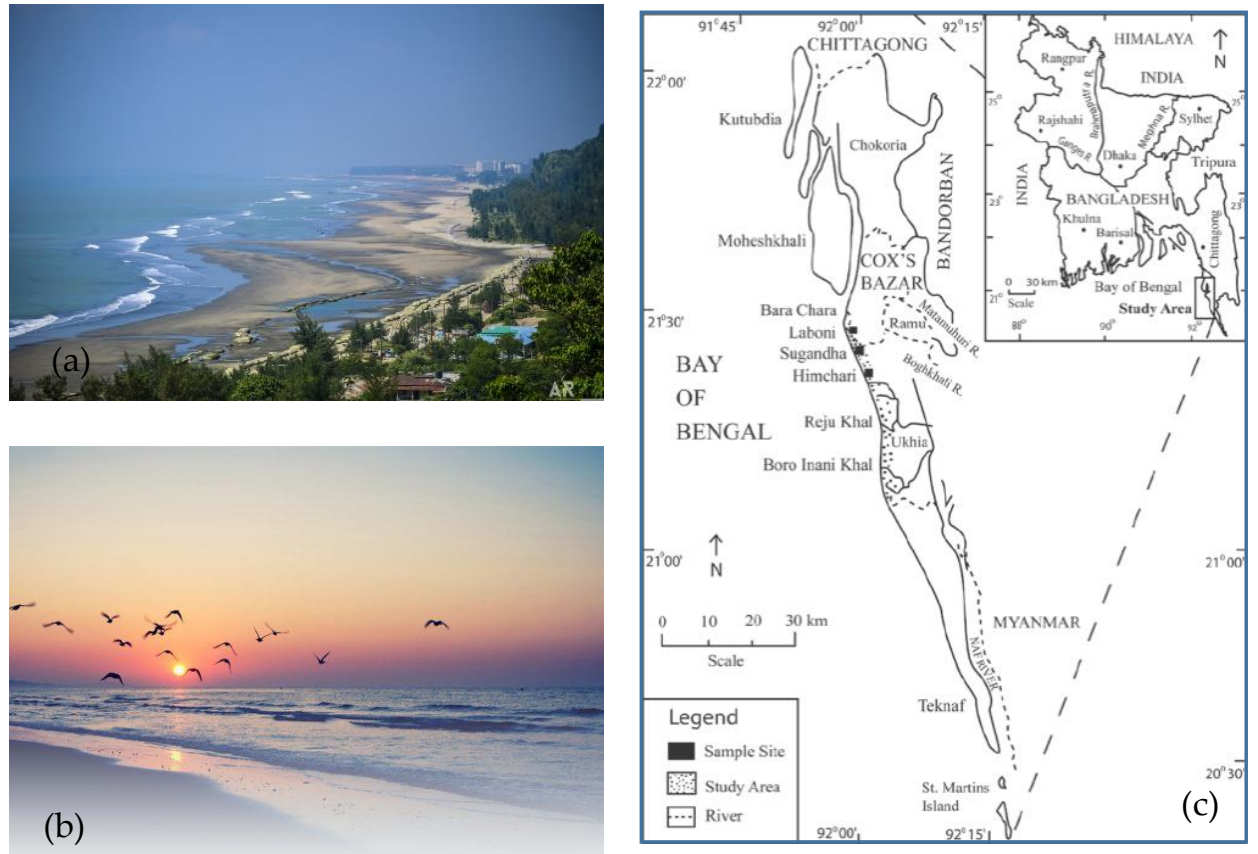

(b)

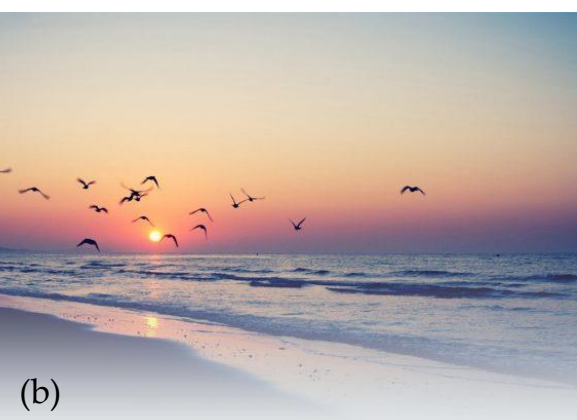

Figure 2. (a) Cox's Bazar Sea beach [67]; (b) Sun set at Cox's Bazar Sea beach [68]; (c) Data collection or sample site in Cox's Bazar Sea beach [69].

\subsection{Research Instrument and Measures}

A self-administered survey questionnaire was designed for data collection. Based on the previous studies, the questionnaire was adapted to this specific case and developed the measurement scales of social media UGC towards the REB (see Appendix A). The research background and objectives of the study were presented at the beginning of the questionnaire. In the first section, information was collected about the measurement scale items. This section comprised questions about cognitive and affective triggers, environmental concern, environmental attitude, and responsible environmental behavior. The second unit consisted of questions about the demographic details of the respondent. Among all measurement items, a 5-point Likert scale was used to analyze respondent approval of the items, where 5 represents the highest approval and 1 represents the most disapproval, ranging from 1 "strongly disagree" to 5 "strongly agree". Likert-type scales are the most commonly used scale to assess the behavioral intentions of travelers [28,44]. Concerning observed variables, four items of cognitive triggers were adopted from Ryan et al. [47], Cheng et al. [58] and four items of affective triggers were adopted from Cheng et al. [58], while four measurement items for environmental concern were from Cheng et al. [58], Yadav et al. [70], and four items of environmental attitude were selected from Ajzen [71], Han [14].Further, four observed items of responsible environmental behavior were adapted from Han [14], Cheng [58], Lee [72].

The questionnaire was constructed in English and tested for content validity by three researchers familiar with tourism studies. The survey was conducted on Bangladeshi domestic tourists, and Brislin's [73] back-translation method was used to ensure uniformity of translation. One native Bangladeshi academic translated the English version questionnaire into Bangla, and another converted the questionnaire back into English to ensure continuity of content. Secondly, a focus group consisting of three professors and six graduate students was requested to review the Bengali sentences to ensure that they were appropriate for reading and comprehension. Some wording of the questionnaire was then updated based on feedback from the focus group participants. 


\subsection{Sampling and Data Collection Procedure}

Due to the lack of a population list (domestic visitors in "Cox's Bazar"), it was not feasible to use a simple random sampling approach in this study. Thus, two types of probability sampling methods were executed to collect the data: multistage cluster sampling and systematic random sampling (SRS). The list of primary sampling units (hotels in "Cox's Bazar") was compiled for sampling. A total of 22 registered hotels were found on the website of the Ministry of Civil Aviation and Tourism, Bangladesh [74]. Among those five are government, and 17 are non-government hotels. In the first stage, we clustered 22 hotels in two groups, government and non-government. In the second stage, three government and nine non-government hotels (total $=12$ hotels) were randomly selected out of 22 using a random number generator from the list of hotels. Considering that each hotel has a capacity of 300 , the total population is 6600 . Then, systematic random sampling was utilized to select samples from the sampling frame. To check any possible human bias in using this method, the first element is selected by a random process. In the next step, the systematic random sampling (SRS) method was used to select the $\mathrm{N} / \mathrm{n}=\mathrm{kth}$ samples. Where, $\mathrm{N}=$ Total population $=6600(300 \times 22=6600$; residents of each hotel, there are 22 registered hotels on the government website), $\mathrm{n}=$ Sample size $=340$ (Confidence level; $+5 \%$ margin of error, $\mathrm{N}=6600 ; \mathrm{n}=$ minimum 340 ), So, $\mathrm{N} / \mathrm{n}=\mathrm{kth},=6600 / 340=19$ th. Thus, each 19 th element from the population (numbered 1-6600) was sampled.

At first, respondents were requested to answer three screening questions: (1) are you an active user of social media? (2) Do you follow any environment-related activities on social media? (3) Have you ever participated, posted, and created any environmentrelated information on social media? The respondents who ensured positive answers, then we proceeded with the rest of the questionnaires. Six-hundred hard copies of the questionnaires were distributed. In the end, 549 responses were received, demonstrating a $91 \%$ return rate. By the conclusion of the study, a total of 506 responses were accepted, with a valid percentage of $92 \%$ after the exclusion of missing information. We considered the sample size sufficient, following the recommendations of Kline [75], who suggest a minimum of 10 cases per variable/item, taking into account that our study consisted of 21 items.

\section{Results}

\subsection{Data Analysis}

Data were analyzed by using SPSS 24 and AMOS 21. As proposed by Anderson and Gerbing [76], a two-stage Structural Equation Modeling (SEM) technique was used to check the proposed model. Initially, a Confirmatory Factor Analysis (CFA) was used to determine the reliability and validity of the measurement model. Finally, the SEM model was used to assess the overall fitness of the model and hypothesized relationships by standardized regression coefficients and $p$-values.

\subsection{Demographic Data}

Among the 506 respondents from Cox's Bazar who participated in the survey, the demographic characteristics were as follows: $57.9 \%$ of them were male and $42.1 \%$ were female. A plurality of respondents was aged $26-33$ years old (53.6\%), followed by 34-41 years old $(24.7 \%), 18-25$ years old $(13.8 \%), 42-49$ years old (5.3\%) and finally 50 years old or above $(2.6 \%)$. A relative majority of the respondents had a bachelor's or a graduate degree $(51.8 \%)$, followed by a masters' degree $(22.7 \%)$, a diploma degree $(15.6 \%)$, high school $(8.3 \%)$, or doctoral degree (1.6\%). A plurality indicated a monthly income between Bangladeshi Taka BDT 40,001-60,000 (39.9\%), followed by BDT 20,001-40,000 (25.1\%), BDT $60,001-80,000(21.5 \%)$, BDT 20,000 or less $(9.9 \%)$, and BDT 80,001 or above $(3.6 \%)$. Moreover, $45.8 \%$ were private sector employees, followed by professionals $(20.8 \%)$, businesspeople $(12.5 \%)$, government employees $(10.1 \%)$, students $(8.7 \%)$, retirees $(1.6 \%)$, and others $(1.2 \%)$. Furthermore, $36.8 \%$ respondents have been using social media for $4-6$ years, followed by $34.2 \%$ for 7 to 9 years, $14.4 \%$ for 1 to 3 years), $10.9 \%$ for more than 10 years, and $3.8 \%$ have 
been using social media for less than one year. Finally, regarding the frequency of social media use, $42.3 \%$ reported 9 or more per day, followed by 7 to 8 times per day $(25.7 \%), 5$ to 6 times $(24.9 \%), 3$ to 4 times per day $(6.5 \%)$, and $0.6 \%$ used social media 0 to 2 times a day. Table 1 shows a summary of the respondents' profiles.

Table 1. Respondents profiles $(n=506)$.

\begin{tabular}{|c|c|c|c|}
\hline Demographic Variable & Gender & $\mathbf{n}$ & $(\%)$ \\
\hline \multirow{2}{*}{ Gender } & Male & 293 & 57.9 \\
\hline & Female & 213 & 42.1 \\
\hline \multirow{5}{*}{ Age group } & $18-25$ years & 70 & 13.8 \\
\hline & $26-33$ years & 271 & 53.6 \\
\hline & $34-41$ years & 125 & 24.7 \\
\hline & $42-49$ years & 27 & 5.3 \\
\hline & 50 years or above & 13 & 2.6 \\
\hline \multirow{5}{*}{ Education } & High school or less & 42 & 8.3 \\
\hline & Diploma certificate & 79 & 15.6 \\
\hline & Bachelor degree & 262 & 51.8 \\
\hline & Master's degree & 115 & 22.7 \\
\hline & Doctoral degree or above & 8 & 1.6 \\
\hline \multirow[t]{5}{*}{ Monthly income (Bangladeshi Taka = BDT) } & BDT 20,000 or less & 50 & 9.9 \\
\hline & BDT 20,001-40,000 & 127 & 25.1 \\
\hline & BDT 40,001-60,000 & 202 & 39.9 \\
\hline & BDT 60,001-80,000 & 109 & 21.5 \\
\hline & BDT 80,001 or above & 18 & 3.6 \\
\hline \multirow[t]{7}{*}{ Employment status } & Student & 44 & 8.7 \\
\hline & Government service & 51 & 10.1 \\
\hline & Private sector & 232 & 45.8 \\
\hline & $\begin{array}{c}\text { Professionals (Teacher, Engineer, Doctor, } \\
\text { Nurse etc.) }\end{array}$ & 102 & 20.2 \\
\hline & Businesspeople & 63 & 12.5 \\
\hline & Retired & 8 & 1.6 \\
\hline & Other & 6 & 1.2 \\
\hline \multirow{5}{*}{$\begin{array}{l}\text { How long have you been using social media } \\
\text { (e.g., Facebook, Instagram, YouTube)? }\end{array}$} & less than 1 year & 19 & 3.8 \\
\hline & $1-3$ years & 73 & 14.4 \\
\hline & $4-6$ years & 186 & 36.8 \\
\hline & 7-9 years & 173 & 34.2 \\
\hline & 10 years or above & 55 & 10.9 \\
\hline \multirow{5}{*}{$\begin{array}{l}\text { How many times per day do you use } \\
\text { social media? }\end{array}$} & $0-2$ times & 3 & 0.6 \\
\hline & $3-4$ times & 33 & 6.5 \\
\hline & $5-6$ times & 126 & 24.9 \\
\hline & $7-8$ times & 130 & 25.7 \\
\hline & 9 times or above & 214 & 42.3 \\
\hline
\end{tabular}

\subsection{Measurement Model: Reliability and Validity}

In the early stages of the evolution of the research model, a common method bias (CMB) was conducted to understand the model fit indices using a widely accepted Harman's one-factor test. Harman's single-factor technique was used in the exploratory factor analysis (EFA) to specify the variance of the common method. A total of $50.147 \%$ of the common variance was observed. It is lower than the suggested value of 70\% by Fuller et al. [77]. Therefore this study does not suffer from the CMB problem.

A confirmatory factor analysis (CFA) was employed to empirically test the measurement model (see Table 2). Cronbach's alpha $(\alpha)$ was used to measure the internal 
consistency and reliability of the scales. The values of Cronbach's $\alpha$ ranged from 0.88 to 0.93 , which exceed the recommended threshold of 0.7 [78], suggesting a strong internal accuracy and reliability. Furthermore, factor loadings, composite reliability (CR), and average variance extracted (AVE) metrics were utilized to assess convergent and discriminant validity [79]. The standardized factor loading for all items was above the threshold of 0.6 [80]. The findings show that the standardized factor loadings of the 21 variables ranged from 0.73 to 0.95 , all of which were above the 0.6 norms [81,82], indicating that all measured variables had a strong explanatory impact on their latent variable. The AVE values were between 0.66 and 0.78 , which reached an acceptable limit of 0.5 as suggested by Hair et al. [78]. The CR values also surpassed the appropriate limit of 0.6 , which ranged from 0.85 to 0.91 , suggesting internal accuracy for multiple measures [75]. Consequently, the measurement scale items of each construct can be considered as having adequate internal consistency.

Table 2. Results of measurement model: reliability and convergent validity test.

\begin{tabular}{cccccccc}
\hline Constructs & Items & Mean & SD & SFL & CR & AVE & Cronbach's Alpha $(\boldsymbol{\alpha})$ \\
\hline \multirow{5}{*}{ Cognitive triggers } & CT1 & 4.34 & 0.656 & 0.730 & 0.85 & 0.66 & 0.93 \\
& CT2 & 4.35 & 0.644 & 0.802 & & & \\
& CT3 & 4.31 & 0.670 & 0.907 & & & \\
& CT4 & 4.36 & 0.643 & 0.806 & & & 0.90 \\
Affective triggers & AT1 & 4.31 & 0.660 & 0.908 & 0.87 & 0.70 & \\
& AT2 & 4.35 & 0.635 & 0.869 & & & \\
& AT3 & 4.18 & 0.713 & 0.736 & & & \\
& AT4 & 4.30 & 0.644 & 0.847 & & 0.88 \\
Environmental & EC1 & 4.28 & 0.688 & 0.883 & 0.91 & 0.77 & \\
concern & EC2 & 4.37 & 0.635 & 0.921 & & & \\
& EC3 & 4.41 & 0.614 & 0.842 & & & \\
\hline \multirow{3}{*}{ Environmental } & EC4 & 4.33 & 0.627 & 0.874 & & & \\
attitude & EA1 & 4.35 & 0.659 & 0.942 & 0.91 & 0.78 & \\
& EA2 & 4.40 & 0.668 & 0.882 & & & \\
\hline \multirow{2}{*}{ EA3 } & 4.39 & 0.620 & 0.838 & & & \\
environmental & EA4 & 4.35 & 0.667 & 0.780 & & & \\
behavior & REB1 & 4.33 & 0.679 & 0.763 & 0.85 & 0.67 & \\
& REB2 & 4.37 & 0.638 & 0.952 & & & \\
\hline & REB3 & 4.37 & 0.690 & 0.726 & & & \\
\hline
\end{tabular}

$\mathrm{SD}=$ Standard Deviation; SFL = Standardized Factor Loading; $\mathrm{CR}=$ Composite Reliability; AVE = Average Variance Extracted.

The maximum likelihood method was used to test the validity of the proposed model when performing CFA. The results show that the measurement model provided a good fit to the data $\left(\chi^{2}=573.382\right.$; comparative fit index (CFI) $=0.958$; goodness of fit index $(\mathrm{GFI})=0.904$; incremental fit index $(\mathrm{IFI})=0.958$; Tucker-Lewis index $(\mathrm{TLI})=0.951$; chisquare/degrees of freedom $(\chi 2 / \mathrm{df})=3.203$; probability level $(p)<0.00$, and root mean square error of approximation $($ RMSEA $)=0.066)$.

\subsection{Discriminant Validity}

In discriminant validity (see Table 3), the AVE values of all constructs (diagonal elements) surpass the square correlations (0.526 to 0.708 ) between any two constructs (off-diagonal elements), which supports it [81]. Furthermore, the square root of AVE (0.812 to 0.883 ) for each construct exceeded the correlations between the given construct and others [75]. Hence, the discriminant validity of the instrument was supported. 
Table 3. Results of discriminant validity.

\begin{tabular}{ccccccc}
\hline & Constructs & CT & AT & EC & EA & REB \\
\hline 1. & Cognitive triggers & 0.812 & & & & \\
2. & Affective triggers & $0.592^{* *}$ & 0.836 & & & \\
3. & Environmental concern & $0.616^{* *}$ & $0.533^{* *}$ & 0.877 & & \\
4. & Environmental attitude & $0.664^{* *}$ & $0.575^{* *}$ & $0.708^{* *}$ & 0.883 & \\
5. & $\begin{array}{c}\text { Responsible } \\
\text { environmental behavior }\end{array}$ & $0.592^{* *}$ & $0.526^{* *}$ & $0.621^{* *}$ & $0.636^{* *}$ & 0.818 \\
\hline
\end{tabular}

Diagonal values are AVE and off-diagonal values are inter-construct squared correlations. ${ }^{* *} p<0.01$.

Henceforth, all differences of the observed variables stated clearly by their latent variables were higher than the variations mentioned by their errors, which represented the average explanatory power of each of the scales in the construct was sufficient. Thus, according to the above findings, the proposed conceptual model has strong validity (convergent and discriminatory) and reliability. Table 3 presents the results of the discriminant values.

\subsection{Structural Model}

The proposed associations were empirically verified based on a covariance matrix. After all the variables in the measurement model were found to reach the applicable threshold in the reliability and validity assessments, the structural model study assumptions were further tested [81]. The structural model was assessed by using a maximum likelihood estimation method and a correlation matrix as input data. Overall model fit indices found that the proposed model adequately reflected the hypothesized relationships. The model fit indices values exceeded the cut-off level $(\chi 2=599.944$; degree of freedom $=3.315$; probability level $<0.001)$. The findings have shown that the goodness of fit statistics of the conceptual framework suggests a good match, because it lies in a satisfying range $(\chi 2=599.944, \chi 2 / \mathrm{df}=3.315$, Goodness of Fit index $(\mathrm{GFI})=0.901$, Adjusted Goodness of fit index $($ AGFI $)=0.874$, Tucker-Lewis Index $(\mathrm{TLI})=0.948$, Comparative Fit Index (CFI) $=0.955$, Incremental Fit Index (IFI) $=0.956$, Root Mean Square Error of Approximation $($ RMSEA $)=0.068$. The measured value of AGFI was 0.930, which exceeds the cut-off level of 0.80 [75]. This outcome represents a good data fit the proposed theoretical framework for travelers' responsible environmental behavioral intention (see Figure 3 and Table 4). From the above analysis, this study tested the hypothesized relationships. The results indicate that the standardized path coefficients are statistically significant in favor of the research hypothesis.

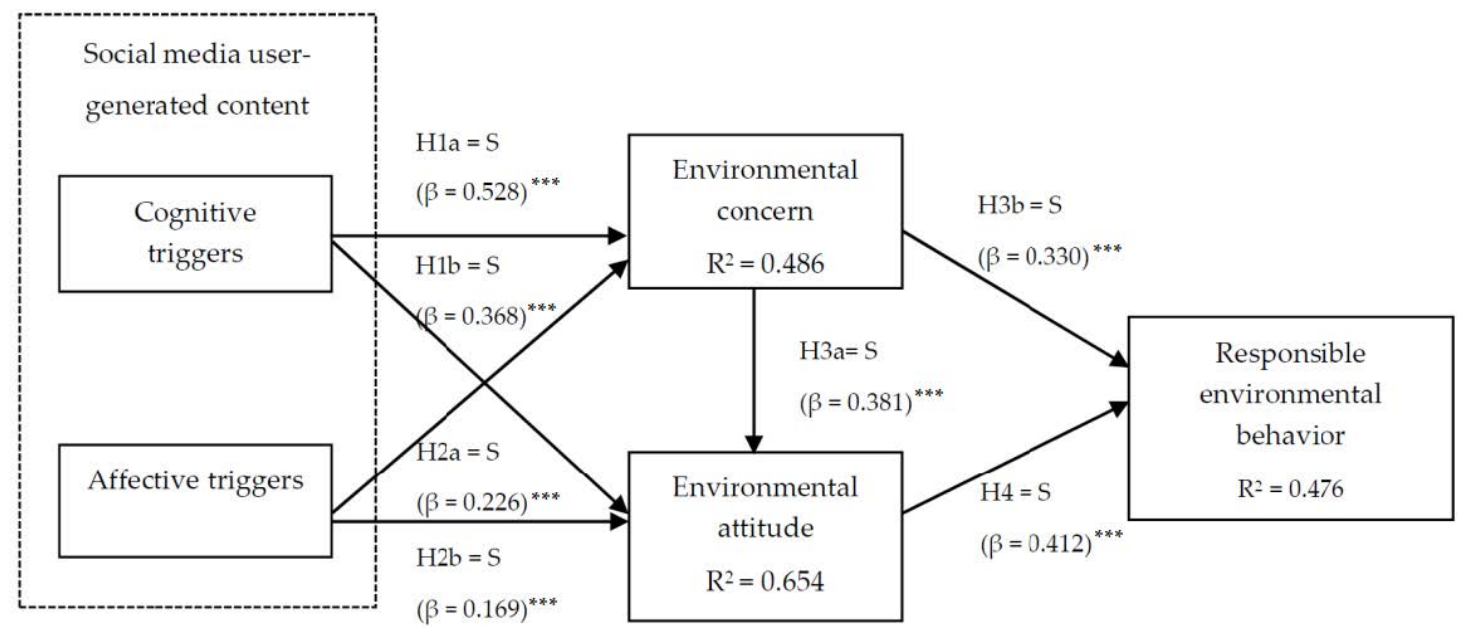

Figure 3. The results of testing the hypothetical model, ${ }^{* * *} p<0.001$. 
Table 4. Summary of hypothesis test results.

\begin{tabular}{ccccc}
\hline Hypothesis & Path & $\beta$-Value & t-Value & Result \\
\hline $\mathrm{H} 1 \mathrm{a}$ & Cognitive triggers $\rightarrow$ Environmental concern & $0.528^{* * *}$ & 9.477 & Supported \\
\hline $\mathrm{H} 1 \mathrm{~b}$ & Cognitive triggers $\rightarrow$ Environmental attitude & $0.368^{* * *}$ & 6.801 & Supported \\
\hline $\mathrm{H} 2 \mathrm{a}$ & Affective triggers $\rightarrow$ Environmental concern & $0.226^{* * *}$ & 4.342 & Supported \\
\hline $\mathrm{H} 2 \mathrm{~b}$ & Affective triggers $\rightarrow$ Environmental attitude & $0.169^{* * *}$ & 3.771 & Supported \\
\hline $\mathrm{H} 3 \mathrm{a}$ & Environmental concern $\rightarrow$ Environmental attitude & $0.381^{* * *}$ & 7.978 & Supported \\
\hline $\mathrm{H} 3 \mathrm{~b}$ & $\begin{array}{c}\text { Environmental concern } \rightarrow \text { Responsible } \\
\text { environmental behavior }\end{array}$ & $0.330^{* * *}$ & 5.811 & Supported \\
\hline $\mathrm{H} 4$ & $\begin{array}{c}\text { Environmental Attitude } \rightarrow \text { Responsible } \\
\text { environmental behavior }\end{array}$ & $0.412^{* * *}$ & 7.015 & Supported \\
\hline
\end{tabular}

\subsection{Hypothesis Testing}

The proposed associations of the variables were empirically tested based on a covariance matrix. After all the variables in the measurement model were found to achieve the relevant threshold in the reliability and validity tests, the structural model study assumptions were further tested. The explained variance $\left(R^{2}\right)$ between dependent and mediating variables, path coefficients $(\beta)$, and their significance levels (t-values) was assessed to determine the statistical significance of the hypothesized relationship. $R^{2}$ for all endogenous constructs was greater than 0.2 , indicating substantial explanatory power [75].

Figure 3 and Table 4 indicate that all of the proposed hypothesized paths (H1a to H4) of the research model are supported. First, cognitive triggers were significantly related with both environmental concerns $\left(\beta=0.528^{* * *}, p<0.001, \mathrm{t}=9.477\right)$, and environmental attitudes $\left(\beta=0.368^{* * *}, p<0.001, \mathrm{t}=6.801\right)$, supporting H1a and H1b. Besides, the relationships between affective triggers and environmental concerns $\left(\beta=0.226^{* * *}, p<^{\prime} 0.001\right.$, $\mathrm{t}=4.342)$, and environmental attitudes $\left(\beta=0.169^{* * *}, p<0.001, \mathrm{t}=3.771\right)$ respectively, were found to be significant, supporting $\mathrm{H} 2 \mathrm{a}$ and $\mathrm{H} 2 \mathrm{~b}$ as well. As expected, environmental concern was significantly associated with environmental attitude $\left(\beta=0.381^{* * *}, p<0.001\right.$, $\mathrm{t}=7.978)$, and responsible environmental behavior $\left(\beta=0.330^{* * *}, p<0.001, \mathrm{t}=5.811\right)$, strongly supporting $\mathrm{H} 3 \mathrm{a}$ and $\mathrm{H} 3 \mathrm{~b}$. Similar results were found for the hypothesis signifying an association between environmental attitude and responsible environmental behavior, which H4 is also supported $\left(\beta=0.412^{* * *}, p<0.001, \mathrm{t}=7.015\right)$. Thus, all seven hypotheses are statistically validated. These results imply that all of the variables of the proposed model were significant towards REB.

\subsection{Indirect-Impact Assessment}

The indirect impact assessment allows further assessments of the mediating role between variables within the proposed model. The roles of the environmental concern, environmental attitude as mediators between cognitive triggers, affective triggers, and responsible environmental behavior were examined via the bootstrapping method (see Table 5). Travelers environmental concerns and environmental attitudes significantly mediated the impact of UGC cognitive triggers on responsible environmental behavior [0.201**; $p<0.001 ; 95 \%$ confidence interval (CI)]. Additionally, environmental concerns significantly mediated the impact of UGC cognitive triggers on responsible environmental behavior $\left[0.174^{* * *} ; p<0.001 ; 95 \%\right.$ confidence interval (CI)]. Finally, environmental attitudes significantly mediated the impact of UGC cognitive triggers on responsible environmental behavior $[0.152 * * * ; p<0.001 ; 95 \%$ confidence interval $(\mathrm{CI})]$. 
Table 5. Results of indirect impact.

\begin{tabular}{|c|c|c|c|c|}
\hline Indirect Path & $\begin{array}{l}\text { Standardized } \\
\text { Estimate }\end{array}$ & $\begin{array}{l}\text { Lower Level } \\
\text { CIs }(95 \%)\end{array}$ & $\begin{array}{l}\text { Upper-Level } \\
\text { CIs }(95 \%)\end{array}$ & $p$-Value \\
\hline $\begin{array}{c}\text { Cognitive triggers } \rightarrow \text { Environmental concern } \rightarrow \\
\text { Environmental attitude } \rightarrow \text { Responsible } \\
\text { environmental behavior }\end{array}$ & $0.201^{* * *}$ & 0.059 & 0.122 & 0.000 \\
\hline $\begin{array}{c}\text { Cognitive triggers } \rightarrow \text { Environmental concern } \rightarrow \\
\text { Responsible environmental behavior }\end{array}$ & $0.174^{* *}$ & 0.115 & 0.254 & 0.001 \\
\hline $\begin{array}{c}\text { Cognitive triggers } \rightarrow \text { Environmental attitude } \rightarrow \\
\text { Responsible environmental behavior }\end{array}$ & $0.152^{* * *}$ & 0.099 & 0.228 & 0.001 \\
\hline $\begin{array}{c}\text { Affective triggers } \rightarrow \text { Environmental concern } \rightarrow \\
\text { Environmental attitude } \rightarrow \text { Responsible } \\
\text { environmental behavior }\end{array}$ & $0.086^{* * *}$ & 0.020 & 0.056 & 0.000 \\
\hline $\begin{array}{l}\text { Affective triggers } \rightarrow \text { Environmental concern } \rightarrow \\
\text { Responsible environmental behavior }\end{array}$ & $0.074^{* * *}$ & 0.038 & 0.112 & 0.001 \\
\hline $\begin{array}{c}\text { Affective triggers } \rightarrow \text { Environmental attitude } \rightarrow \\
\text { Responsible environmental behavior }\end{array}$ & $0.070^{* * *}$ & 0.036 & 0.106 & 0.001 \\
\hline
\end{tabular}

${ }^{* * *} p<0.001 ;{ }^{* *} p<0.010$.

\section{Discussion and Implications}

Social media UGC has become a valuable source of knowledge for the conceptualization of the natural environmental sustainable process. In general, sustainability is a significant issue that well discussions on social networks, which predominantly linked to travelers sustainable environmental behavior. For around three decades, sustainable responsible behavior has been identified as an optimal approach for the effective management of tourism destinations. Sustainable use of tourism resources, including infrastructure, transport, accommodation, and responsible action by tourists, remains a challenge for local tourism management. The emergence of information and communication technologies and the existence of social media are dramatically changing at this point [83]. While many studies have shown that social media has a strong effect on the behavior of travelers, its impact on sustainable coastal tourism is not sufficiently documented.

This study aims to understand the effect of UGC on the responsible environmental behavior of travelers. To measure this relationship, our study proposed five hypotheses and conducted self-administered survey-based research. The questionnaire was designed to examine the effects of cognitive and affective triggers on environmental concerns and awareness towards responsible environmental behavior. The findings of our research offered significant support to the hypothesis that cognitive and affective triggers of UGC are linked to environmental concerns and understanding, as these factors enhance tourists ${ }^{\prime}$ responsible environmental practice. Most notably, travelers engagement and interaction on social media about environmental issues increase awareness of sustainable responsible environmental behavior towards coastal tourism. This research also focused on the effectiveness of UGC in accumulating persuasive communications towards sustainable travel behavior [84]. Since the last decade, virtual networks have become mainstream interpersonal communication tools that proactively produce environment-related content to alter individual attitudes. The current findings also follow the results of previous research $[83,85,86]$. From a hypothetical relationship analysis, this study proposed that social media UGC has a significant impact on shaping their responsible environmental behavior towards coastal tourism. Several studies have focused on how the engagement of social media influences the environmentalist ideological activity of an individual and put their contributions into social change towards sustainable practice [34,41,42]. We consider our study's most interesting contribution to be the association between cognitive and affective triggers of UGC with mediating variables, namely environmental awareness and 
environmental concern. Both factors have an extremely important effect on responsible environmental behavior. To this end, our study explored the potential power of social media on an individual's psychological conversion to responsible environmental behavior. Nevertheless, we also identified a strong link between environmental awareness and environmental attitude, which could contribute to the indirect relationship between the cognitive and affective influence of UGC on REB. The results of this study found strong associations among constructs, which were consistent with the previous research findings regarding individuals' responsible environmental behavior [85]. Tourists with greater environmental awareness tend to act more responsibly towards the environment and feel a greater moral obligation to conduct responsible environmental behavior.

\subsection{Theoretical Implications}

The current study displays several academic or theoretical implications. At first, this research is the first empirical approach and analysis focused on social media UGC that made a connection with the REB of tourists towards coastal tourism. Additionally, it is a theoretical contribution to filling the existing knowledge gap by suggesting the appropriate implication of social media UGC in sustaining REB. The conceptual model combines the cognitive and affective triggers of the UGC and offers an important framework to examine travelers attitudes towards responsible environmental actions and contribution to the sustainable use of destination resources. Secondly, the concept of cognitive and affective triggers of UGC adaptation to the development of REB in the social media context has validated the initial model for future academic research. The hypothetical findings of the study are useful in understanding REB from a range of theoretical perspectives towards sustainable coastal tourism. The aspects of UGC have been mediated by environmental awareness and an environmental attitude to strengthen REB. Thirdly, this is the first study of REB behavior aiming to understand the relationship between environmental awareness and attitude influence by social media UGC, and we assume that the findings of this research will provide insightful recommendations for future research.

\subsection{Practical Implications}

The findings of this research will help to institute coastal tourism marketing approaches for destinations that will lead to the improvement of sustainable environmental actions towards coastal tourism destinations. Thus, the following practical implications need to be implemented:

The destination marketing organizations (DMOs) should enhance environmental awareness through social media campaigns to encourage travelers to take responsible actions towards coastal destinations. To improve the attitudes of tourists towards responsible practices, DMOs should reinforce environmental awareness, initiatives, and promotions via social media to help visitors understand the significance and importance of environmental conservation. Besides, destination managers should develop promotional articles or documentaries with slogans and visual narratives that enable tourists to be introspective and consider the significant harm caused by uncivilized behavior. Therefore, DMOs should adopt the appropriate approach of interactive communication, engaging through social media communities, and implementing the strategies of responsible use of tourism assets.

The results of the study indicate that UGC has provided adequate knowledge and evidence to improve an individual's responsible sensitivity towards environmental awareness. As a result, the findings of this study provide possibilities for DMOs to reshape there marketing strategies. They may participate in constructive interaction and engagement across the social media community with their prospective tourists'. DMOs can encourage travelers to participate proactively in social media to discuss environmental issues related to coastal tourism and to share their experiences and opinions with the community. This will be the most influential source of information to increase traveler environmental awareness of sustainable coastal tourism. 
In this context of travel content marketing, DMOs could reinforce or transform the responsible attitudes and optimistic psychology tourists to perform sustainable responsible environmental behavior. This approach will help minimize their negative impacts and to have a positive impact on the sustainable management of the resources. For example, the Administration could organize coastal tourism festivals to promote sustainability awareness through a social media campaign and engage tourists to share their real-time experience of coastal environmental conservation practice. Such participative activity with long-term engagement strategies through social media would certainly enhance travelers motivation to change their general behavior towards more sustainable practices [87].

\section{Conclusions}

This research work provides several new insights into the field of responsible environmental behavior towards sustainable coastal tourism through social media UGC. The findings of this study show that cognitive triggers and affective triggers of UGC are useful in investigating individual responsible environmental behavior, as mediated by environmental concerns and attitudes. The proposed conceptual model could help in further REB studies. The results of this study will raise interest in further research to identify other factors that may lead to sustainable coastal tourism practices. Besides, the proposed model could be restructured with different aspects to measure travelers' sustainable behavior.

\section{Limitations and Future Research Recommendation}

This study encountered certain limitations that should also be taken into account for further research. Firstly, we did not consider the perspectives of users of specific social media platforms (i.e., Facebook), which could contribute to better understanding what features of social media (i.e., pictures, video, live streaming, storyboard, graphic presentation) influence REB the most. Therefore, future studies should examine the strength of the proposed model for a specific source of information related to the environment. Secondly, the factors involved in this research have been inspected at one time. Future studies should, therefore, use the pre-and post-response assessment to verify the proposed model. Finally, future studies could use the focus group discussion (FGD) or in-depth interviews to determine the REB factors.

Author Contributions: Conceptualization: M.T.S. and F.S.; methodology: M.T.S. and F.S.; software, M.T.S.; validation, M.T.S. and F.S.; formal analysis, M.T.S., F.S., A.B. and E.S.; investigation: F.S. and K.X.; resources: K.X. and A.B.; data curation: F.S. and M.T.S.; writing-original draft preparation: M.T.S. and F.S. writing-review and editing: A.B., E.S., and K.X.; project administration and supervision: K.X. All authors have read and agreed to the published version of the manuscript.

Funding: This research received no external funding.

Conflicts of Interest: The authors declare no conflict of interest.

Appendix A. Measuring items, and their source of adoption 
Table A1. Constructs and Scale Items.

\begin{tabular}{llc}
\hline Latent Variable & \multicolumn{1}{c}{ Item Text } & Source of Adoption \\
\hline & $\begin{array}{l}\text { CT1: I know that the maintenance of ecological balance will enhance } \\
\text { the sustainable development of the coastal area. } \\
\text { CT2: I know that the maintenance of the diversity of species on the } \\
\text { Coastal region will balance the ecology. } \\
\text { CT3: I believe that in the coastal region travelers are partly responsible } \\
\text { for environmental problems. } \\
\text { CT4: I know that the maintenance of ecological balance will enhance } \\
\text { the sustainable development of the coastal regions. }\end{array}$ & \\
\hline
\end{tabular}

AT1: I am concerned about ecological preservation in the coastal area.

AT2: I know that excessive ocean recreational activities will damage

the oceanic environments of the coastal area.

Affective triggers AT3: I care about the impact of my living habits on the natural

environments of the coastal area.

AT4: I know that extensive tourism development will sacrifice natural resources and environments.

EC1: I am concerned about the ecological preservation of the coastal area.

Environmental

EC2: I care about the impact of my living habits on the natural

concern environments of the coastal area.

EC3: Environmental sustainability is crucial for the long-term success of coastal and maritime tourism.

EC4: Human beings are severely abusing the coastal environment.

EA1: I think protecting the coastal environment of the scenic spot is wise.

EA2: I think protecting the coastal environment of the scenic spot is

Environmental good.

attitude EA3: I think protecting the coastal environment of the scenic spot is worthwhile.

EA4: I think protecting the coastal environment of the scenic spot is beneficial.

REB1: I follow the tourism regulations of the administration of the scenic spot.

Responsible REB2: I protect the facilities of the scenic spot from being destroyed.

environmental REB3: I protect the facilities of the scenic spot from being destroyed. behavior REB4: I do reasonable disposal of wastes incurred during my travel. REB5: I participate in activities to clean the beach (such as picking up trash on the beach.

\section{References}

1. Marzetti, S.; Disegna, M.; Koutrakis, E.; Sapounidis, A.; Marin, V.; Martino, S.; Roussel, S.; Rey-Valette, H.; Paoli, C. Visitors' awareness of ICZM and WTP for beach preservation in four European Mediterranean regions. Mar. Policy 2016, 63, 100-108. [CrossRef]

2. Kenchington, R. Tourism in coastal and marine environments-a recreational perspective. Ocean Coast. Manag. 1993, 19, 1-16. [CrossRef]

3. Needham, M.D.; Szuster, B.W. Situational influences on normative evaluations of coastal tourism and recreation management strategies in Hawai'i. Tour. Manag. 2011, 32, 732-740. [CrossRef]

4. Botero, C.-M.; Pereira, C.; Anfuso, G.; Cervantes, O.; Williams, A.T.; Pranzini, E.; Silva, C.P. Recreational parameters as an assessment tool for beach quality. J. Coast. Res. 2014, 70, 556-562. [CrossRef]

5. Houston, J.R. The Economic Value of Beaches-A 2002 Update. Shore Beach 2013, 81, 3-11.

6. Dos Anjos, F.A.; de Lima Pereira, M.; Tennenberg, F.F.P. Von Evaluation of the image of a coastal tourism destination in Brazil. Int. J. Tour. Cities 2017, 3, 324-338. [CrossRef]

7. Kubo, T.; Uryu, S.; Yamano, H.; Tsuge, T.; Yamakita, T.; Shirayama, Y. Mobile phone network data reveal nationwide economic value of coastal tourism under climate change. Tour. Manag. 2020, 77, 104010. [CrossRef] 
8. Koens, K.; Postma, A.; Papp, B. Is overtourism overused? Understanding the impact of tourism in a city context. Sustainability 2018, 10, 4384. [CrossRef]

9. Blignaut, J.; Mander, M.; Inglesi-Lotz, R.; Glavan, J.; Parr, S. The amenity value of Abu Dhabi's coastal and marine resources to its beach visitors. Ecosyst. Serv. 2016, 19, 32-41. [CrossRef]

10. Merli, R.; Preziosi, M.; Acampora, A.; Lucchetti, M.C.; Ali, F. The impact of green practices in coastal tourism: An empirical investigation on an eco-labelled beach club. Int. J. Hosp. Manag. 2019, 77, 471-482. [CrossRef]

11. Semeoshenkova, V.; Newton, A. Overview of erosion and beach quality issues in three Southern European countries: Portugal, Spain and Italy. Ocean Coast. Manag. 2015, 118, 12-21. [CrossRef]

12. Juvan, E.; Dolnicar, S. The attitude-behaviour gap in sustainable tourism. Ann. Tour. Res. 2014, 48, 76-95. [CrossRef]

13. Bronfman, N.C.; Cisternas, P.C.; López-Vázquez, E.; De la Maza, C.; Oyanedel, J.C. Understanding attitudes and proenvironmental behaviors in a Chilean community. Sustainability 2015, 7, 14133-14152. [CrossRef]

14. Han, W.; McCabe, S.; Wang, Y.; Chong, A.Y.L. Evaluating user-generated content in social media: An effective approach to encourage greater pro-environmental behavior in tourism? J. Sustain. Tour. 2018, 26, 600-614. [CrossRef]

15. Hargreaves, T. Practice-ing behaviour change: Applying social practice theory to pro-environmental behaviour change. J. Consum. Cult. 2011, 11, 79-99. [CrossRef]

16. Charter, M. Greener Marketing: A Responsible Approach to Business; Greenleaf Publishing: Sheffield, UK, 1992.

17. Buckley, R. Sustainable tourism: Research and reality. Ann. Tour. Res. 2012, 39, 528-546. [CrossRef]

18. Mensah, I. Environmental management practices among hotels in the greater Accra region. Int. J. Hosp. Manag. 2006, 25, 414-431. [CrossRef]

19. Yusof, N.; Rahman, S.; Iranmanesh, M. The environmental practice of resorts and tourist loyalty: The role of environmental knowledge, concern, and behaviour. Anatolia 2016, 27, 214-226. [CrossRef]

20. Dodds, R.; Holmes, M. Is there a Benefit from being Green? Assessing Benefits from Marketing Sustainability by North American Hotels. J. Hotel Bus. Manag. 2016, 5, 145. [CrossRef]

21. Tölkes, C. Sustainability communication in tourism-A literature review. Tour. Manag. Perspect. 2018, 27, 10-21. [CrossRef]

22. Abdullah, S.I.N.W.; Samdin, Z.; Teng, P.K.; Heng, B.L.J. The impact of knowledge, attitude, consumption values and destination image on tourists' responsible environmental behaviour intention. Manag. Sci. Lett. 2019, 9, 1461-1476. [CrossRef]

23. Chung, N.; Koo, C. The use of social media in travel information search. Telemat. Inform. 2015, 32, 215-229. [CrossRef]

24. Kim, S.E.; Lee, K.Y.; Shin, S.I.; Yang, S.B. Effects of tourism information quality in social media on destination image formation: The case of Sina Weibo. Inf. Manag. 2017. [CrossRef]

25. Tsiakali, K. User-generated-content versus marketing-generated-content: Personality and content influence on traveler's behavior. J. Hosp. Mark. Manag. 2018, 27, 946-972. [CrossRef]

26. Barber, N.; Taylor, C.; Strick, S. Wine consumers ' environmental knowledge and attitudes: In fl uence on willingness to purchase. Int. J. Wine Res. 2009, 1, 59-72. [CrossRef]

27. Kane, K.; Chiru, C.; Ciuchete, S.G. Exploring the eco-attitudes and buying behaviour of Facebook users. Amfiteatru Econ. 2012, $14,157-171$.

28. Verma, V.K.; Chandra, B.; Kumar, S. Values and ascribed responsibility to predict consumers' attitude and concern towards green hotel visit intention. J. Bus. Res. 2019, 96, 206-216. [CrossRef]

29. WCED. Our Common Future; Oxford University Press: New York, NY, USA, 1987.

30. Nations, U.; Programme, E. Making Tourism More Sustainable—A Guide for Policy Makers; UNEP: Paris, France, 2005.

31. Hall, C.M. Trends in ocean and coastal tourism: The end of the last frontier? Ocean Coast. Manag. 2001, 44, 601-618. [CrossRef]

32. Ferrante, M.; Lo Magno, G.L.; De Cantis, S. Measuring tourism seasonality across European countries. Tour. Manag. 2018, 68, 220-235. [CrossRef]

33. Drius, M.; Bongiorni, L.; Depellegrin, D.; Menegon, S.; Pugnetti, A.; Stifter, S. Tackling challenges for Mediterranean sustainable coastal tourism: An ecosystem service perspective. Sci. Total Environ. 2019, 652, 1302-1317. [CrossRef]

34. Langley, D.; Van Den Broek, T. Exploring social media as a driver of sustainable behaviour: Case analysis and policy implications. In Proceedings of the Internet Politics and Policy Conference 2010, Oxford, UK, 16-17 September 2010; p. 28.

35. Zahid, M.M.; Ali, B.; Ahmad, M.S.; Thurasamy, R.; Amin, N. Factors Affecting Purchase Intention and Social Media Publicity of Green Products: The Mediating Role of Concern for Consequences. Corp. Soc. Responsib. Environ. Manag. 2018, 25, 225-236. [CrossRef]

36. Jedrzejczak, M.F. The modern tourist' s perception of the beach: Is the sandy beach a place of conflict between tourism and biodiversity? Coastline Rep. 2004, 2, 109-119.

37. Campbell, M.L.; Slavin, C.; Grage, A.; Kinslow, A. Human health impacts from litter on beaches and associated perceptions: A case study of 'clean' Tasmanian beaches. Ocean Coast. Manag. 2016, 126, 22-30. [CrossRef]

38. Kladou, S.; Kavaratizis, M.; Rigopoulou, E.; Salonika, E. The role of brand elements in destination branding. J. Destin. Mark. Manag. 2017, 6, 426-435. [CrossRef]

39. Wyles, K.J.; White, M.P.; Hattam, C.; Pahl, S.; King, H.; Austen, M.C.V. Are Some Natural Environments More Psychologically Beneficial Than Others? The Importance of Type and Quality on Connectedness to Nature and Psychological Restoration. Environ. Behav. 2019. [CrossRef] 
40. Daugherty, T.; Eastin, M.S.; Bright, L. Exploring Consumer Motivations for Creating User-Generated Content. J. Interact. Advert. 2008, 8, 16-25. [CrossRef]

41. Ryan, A.; Spash, C.L. Measuring "Awareness of environmental consequences": Two scales and two interpretations. CSIRO Work. Pap. Ser. 2008, 37. [CrossRef]

42. Van Riper, C.J.; Kyle, G.T. Understanding the internal processes of behavioral engagement in a national park: A latent variable path analysis of the value-belief-norm theory. J. Environ. Psychol. 2014, 38, 288-297. [CrossRef]

43. Calcagni, F.; Amorim Maia, A.T.; Connolly, J.J.T.; Langemeyer, J. Digital co-construction of relational values: Understanding the role of social media for sustainability. Sustain. Sci. 2019, 14, 1309-1321. [CrossRef]

44. Luck, E.; Ginanti, A. Online Environmental Citizenship: Blogs, Green Marketing and consumer sentiment in the 21st Century. Electron. Green J. 2013, 1. [CrossRef]

45. Casaló, L.V.; Flavián, C.; Guinalíu, M. Determinants of the intention to participate in firm-hosted online travel communities and effects on consumer behavioral intentions. Tour. Manag. 2010, 31, 898-911. [CrossRef]

46. Cheng, T.M.; Wu, H.C. How do environmental knowledge, environmental sensitivity, and place attachment affect environmentally responsible behavior? An integrated approach for sustainable island tourism. J. Sustain. Tour. 2015, 23, 557-576. [CrossRef]

47. Hardeman, G.; Font, X.; Nawijn, J. The power of persuasive communication to influence sustainable holiday choices: Appealing to self- benefits and norms. Tour. Manag. 2017, 1-20. [CrossRef]

48. Fishbein, M.; Ajzen, I. Attitude formation. Belief Attitude Intent. Behav. Introd. Theory Res. 1975, 216-287. [CrossRef]

49. D'Souza, C.; Taghian, M.; Khosla, R. Examination of environmental beliefs and its impact on the influence of price, quality and demographic characteristics with respect to green purchase intention. J. Target. Meas. Anal. Mark. 2007, 15, 69-78. [CrossRef]

50. Kim, W.H.; Kim, K.S. Pro-environmental intentions among food festival attendees: An application of the value-belief-norm model. Sustainability 2018, 10, 3894. [CrossRef]

51. Ajzen, I. The Theory of Planned Behavior. Organ. Sci. 1991, 50, 179-211. [CrossRef]

52. Hungerford, H.R.; Volk, T.L. Changing learner behavior through environmental education. J. Environ. Educ. 1990, 21, 8-21. [CrossRef]

53. Bagozzi, R.P.; Gopinath, M.; Nyer, P.U. The role of emotions in marketing. J. Acad. Mark. Sci. 1999, 27, 184-206. [CrossRef]

54. Varela-Candamio, L.; Novo-Corti, I.; García-Álvarez, M.T. The importance of environmental education in the determinants of green behavior: A meta-analysis approach. J. Clean. Prod. 2018, 170, 1565-1578. [CrossRef]

55. Roberts, J.A. Green consumers in the 1990s: Profile and implications for advertising. J. Bus. Res. 1996, 36, 217-231. [CrossRef]

56. Kilbourne, W.; Pickett, G. How materialism affects environmental beliefs, concern, and environmentally responsible behavior. J. Bus. Res. 2008, 61, 885-893. [CrossRef]

57. Chan, R.Y.K.; Lau, L.B.Y. Antecedents of green purchases: A survey in China. J. Consum. Mark. 2000, 17, 338-357. [CrossRef]

58. Hjalager, A. Relational Environmentalism in Coastal Recreation and Tourism. Sustainability 2019, 11, 6011. [CrossRef]

59. Dolnicar, S.; Grün, B. Environmentally friendly behavior: Can heterogeneity among individuals and contexts/environments be harvested for improved sustainable management? Environ. Behav. 2009, 41, 693-714. [CrossRef]

60. Wang, C.; Zhang, J.; Yu, P.; Hu, H. The theory of planned behavior as a model for understanding tourists' responsible environmental behaviors: The moderating role of environmental interpretations. J. Clean. Prod. 2018, 194, 425-434. [CrossRef]

61. Kollmuss, A.; Agyeman, J. Mind the Gap: Why do people act environmentally and what are the barriers to pro-environmental behavior? Environ. Educ. Res. 2002, 8, 239-260. [CrossRef]

62. Chen, M.F.; Tung, P.J. Developing an extended Theory of Planned Behavior model to predict consumers' intention to visit green hotels. Int. J. Hosp. Manag. 2014, 36, 221-230. [CrossRef]

63. Follows, S.B.; Jobber, D. Environmentally responsible consumer model. Eur. J. Mark. 2000, 34, 723-746. [CrossRef]

64. Baker, M.A.; Davis, E.A.; Weaver, P.A. Eco-friendly Attitudes, Barriers to Participation, and Differences in Behavior at Green Hotels. Cornell Hosp. Q. 2014, 55, 89-99. [CrossRef]

65. Mohaidin, Z.; Wei, K.T.; Murshid, M.A. Factors influencing the tourists ' intention to select sustainable tourism destination: A case study of Penang, Malaysia. Int. J. Tour. CITIES 2017, 3, 442-465. [CrossRef]

66. Stern, P.C. Toward a coherent theory of environmentally significant behavior. J. Soc. Issues 2000, 56, 407-424. [CrossRef]

67. Burgess, J.; Harrison, C.M.; Filius, P. Environmental communication and the cultural politics of environmental citizenship. Environ. Plan. A 1998, 30, 1445-1460. [CrossRef]

68. Lehman, P.K.; Geller, E.S. Behavior Analysis And Environmental Protection: Accomplishments And Potential For More. Behav. Soc. Issues 2004, 13-32. [CrossRef]

69. Hines, J.M.; Hungerford, H.R.; Tomera, A.N. Analysis and synthesis of research on responsible environmental behavior: A metaanalysis. J. Environ. Educ. 1987, 18, 1-8. [CrossRef]

70. Msramjan “Coxs Bazar” The largest sea beach in the world. Available online: https://steemit.com/photography/@msramjan/ coxs-bazar-the-largest-sea-beach-in-the-world (accessed on 12 September 2020).

71. Club, B. Cox's Bazar, Bangladesh. Available online: https://tl.fanpop.com/clubs/bangladesh/images/41724961/title/coxsbazar-bangladesh-photo (accessed on 12 August 2020).

72. Zakir Hossain, H.M.; Tarek, M.; Armstrong-Altrin, J.S.; Monir, M.M.U.; Ahmed, M.T.; Ahmed, S.I.; Hernandez-Coronado, C.J. Microtextures of detrital sand grains from the cox's bazar beach, Bangladesh: Implications for provenance and depositional environment. Carpathian J. Earth Environ. Sci. 2014, 9, 187-197. 
73. Yadav, R.; Pathak, G.S. Young consumers' intention towards buying green products in a developing nation: Extending the theory of planned behavior. J. Clean. Prod. 2016, 135, 732-739. [CrossRef]

74. Lee, T.H.; Jan, F.H.; Huang, G.W. The influence of recreation experiences on environmentally responsible behavior: The case of Liuqiu Island, Taiwan. J. Sustain. Tour. 2015, 23, 947-967. [CrossRef]

75. Brislin, R.W. Back-Translation For Cross-Cultural Research. J. Cross. Cult. Psychol. 1970, 1, 185-216. [CrossRef]

76. District, C.B. Accomodation in Cox's Bazar Available online: http://www.coxsbazar.gov.bd/site/view/hotel/হ• •াটলে ও আবাসন (accessed on 15 June 2018).

77. Kline, R.B. Principles and Practice of Structural Equation Modeling, 3rd ed.; The Guildford Press: New York, NY, USA, 2011; ISBN 978-1-60623-876-9.

78. Gerbing, D.W.; Anderson, J.C. Structural equation modeling in practice: A review and recommended two-step approach. Psychol. Bull. 1988, 103, 411-423.

79. Fuller, C.M.; Simmering, M.J.; Atinc, G.; Atinc, Y.; Babin, B.J. Common methods variance detection in business research. J. Bus. Res. 2016, 69, 3192-3198. [CrossRef]

80. Hair, J.F.; Black, W.C.; Babin, B.J.; Anderson, R.E. Multivariate Data Analysis; Pearson: London, UK, 2014 ; ISBN 9781292021904.

81. Straub, D.; Gefen, D. Validation Guidelines for IS Positivist Research. Commun. Assoc. Inf. Syst. 2004, 13. [CrossRef]

82. Chin, W.W.; Gopal, A.; Salisbury, W.D. Advancing the Theory of Adaptive Structuration: The Development of a Scale to Measure Faithfulness of Appropriation. Inf. Syst. Res. 1997, 8, 342-367. [CrossRef]

83. Bagozzi, R.P.; Yi, Y. On the evaluation of structural equation models. J. Acad. Mark. Sci. 1988, 16, 74-94. [CrossRef]

84. Fornell, C.; Larcker, D.F. Evaluating Structural Equation Models with Unobservable Variables and Measurement Error. J. Mark. Res. 1981, 18, 39-50. [CrossRef]

85. Joo, Y.; Seok, H.; Nam, Y. The moderating effect of social media use on sustainable rural tourism: A theory of planned behavior model. Sustainability 2020, 12, 4095. [CrossRef]

86. Bilgihan, A.; Barreda, A.; Okumus, F.; Nusair, K. Consumer perception of knowledge-sharing in travel-related OnlineSocial Networks. Tour. Manag. 2016, 52, 287-296. [CrossRef]

87. Kaosiri, Y.N.; Fiol, L.J.C.; Tena, M.Á.M.; Artola, R.M.R.; García, J.S. User-Generated Content Sources in Social Media: A New Approach to Explore Tourist Satisfaction. J. Travel Res. 2019, 58, 253-265. [CrossRef] 